\title{
DUKUNGAN KELUARGA: FAKTOR PENYEBAB KETIDAKPATUHAN KLIEN SKIZOFRENIA MENJALANI PENGOBATAN
}

\author{
Ice Yulia Wardani ${ }^{1^{*}}$, Achir Yani S. Hamid ${ }^{1}$, Wiwin Wiarsih ${ }^{1}$, Herni Susanti ${ }^{1}$ \\ 1. Fakultas Ilmu Keperawatan Universitas Indonesia, Depok 16424, Indonesia \\ *Email:iceyulia@ui.ac.id
}

\begin{abstract}
Abstrak
Ketidakpatuhan terhadap pengobatan merupakan masalah yang banyak dialami oleh klien skizofrenia. Keluarga sebagai caregiver di rumah dituntut untuk mampu mengatasi masalah ini. Penelitian ini bertujuan untuk mendapatkan pemahaman mendalam tentang makna pengalaman menghadapi ketidakpatuhan anggota keluarga dengan skizofrenia dalam mengikuti regimen terapeutik: pengobatan. Penelitian ini menggunakan desain fenomenologi deskriptif. Partisipan adalah caregiver yang didapatkan dengan cara purposive sampling. Metode pengumpulan data adalah indepth interview. Hasil wawancara dianalisis menggunakan teknik Collaizi. Hasil penelitian ini menggambarkan pengalaman keluarga dalam merawat anggota keluarga yang tidak patuh terhadap pengobatan, meliputi dukungan yang diberikan, beban yang dirasakan, dan bagaimana keluarga mengatasi beban yang dirasakan. Temuan penelitian ini dapat digunakan sebagai acuan oleh praktisi keperawatan untuk mengembangkan cara penanganan ketidakpatuhan klien skizofrenia.
\end{abstract}

Kata kunci: dukungan keluarga, ketidakpatuhan, pengalaman keluarga, skizofrenia

\begin{abstract}
The non-compliance to the treatment is the common issue among the patients with schizophrenia. Family as the main caregiver at home was being charged to be able to solve this problem. The objective of the study was to understand deeply about the family experiences in facing the non-compliance the treatment of patient with schizophrenia. This study used the phenomenology descriptive design. The participants were the patient's caregiver and they were taken by using purposive sampling technique. The method used for collecting data was in-depth interview. The interview's transcript was then analyzed by using the Collaizi method. The finding of this study described the family experience in treating the family member with non-compliance to the treatment, including the support given, the burden felt by the care giver, and the strategy used to ease the burden. The findings of this study can be used as reference by the nursing practitioners to develop the strategy to solve the non-compliance of patients with schizophrenia.
\end{abstract}

Keywords: family's experience, family's support, non-compliance, schizophrenia

\section{Pendahuluan}

Ketidakmampuan seseorang dalam mengatasi sumber stress dapat mengakibatkan terjadinya gangguan mental emosional yang sering kali berujung pada terjadinya gangguan jiwa. Salah satu jenis gangguan jiwa berat adalah skizofrenia. Skizofrenia merupakan sekelompok reaksi psikotik yang mempengaruhi berbagai fungsi individu, termasuk fungsi berpikir dan berkomunikasi, menerima dan menginterpretasikan realitas, merasakan dan menunjukkan emosi, serta berperilaku tidak rasional (Stuart \& Laraia, 2005).

Salah satu masalah dalam penanganan skizofrenia adalah kekambuhan. Kekambuhan yang terjadi pada satu tahun pertama setelah terdiagnosa skizofrenia dialami oleh $60-70 \%$ klien yang tidak mendapat terapi medikasi; $40 \%$ klien yang hanya mendapat medikasi; $15,7 \%$ pada klien yang mendapat kombinasi terapi medikasi, psikoterapi, dan mendapat dukungan dari tenaga kesehatan, keluarga dan masyarakat (Olfson, et al., 2000 dalam Stuart \& Laraia, 2005). Hasil studi literatur dan pengalaman peneliti sebagai praktisi keperawatan jiwa menunjukkan fenomena kekambuhan lebih banyak diakibatkan oleh putus obat. Hasil survei yang dilakukan oleh World Federation of Mental Health 2006 terhadap 982 keluarga yang mempunyai anggota keluarga dengan gangguan jiwa menunjukkan 51\% klien kambuh akibat berhenti minum obat, dan 49\% kambuh akibat mengubah dosis obat sendiri. 
Keluarga sebagai caregiver memegang peranan penting dalam mendukung kepatuhan klien gangguan jiwa terhadap regimen terapi yang diberikan. Di RSMM Bogor, keluarga klien yang dirawat mendapatkan pendidikan kesehatan sebanyak satu atau dua kali pertemuan setiap minggu, termasuk melibatkan mereka dalam merawat anggota keluarganya yang masih dirawat di sini. Paket pendidikan kesehatan yang diberikan adalah cara merawat anggota keluarga sesuai dengan masalah keperawatan yang dialami. Akan tetapi kenyataannya masih banyak klien di ruangan ini yang mengalami kekambuhan akibat ketidakpatuhan menjalani pengobatan. Berdasarkan uraian tersebut, penelitian dilakukan untuk mempelajari pengalaman keluarga menghadapi ketidakpatuhan klien skizofrenia menjalani regimen terapi pengobatan.

\section{Metode}

Penelitian ini menggunakan desain penelitian riset kualitatif dengan metode fenomenologi deskriptif yang mengeksplorasi, menganalisis, dan mendeskripsikan fenomena sosial, serta berusaha memahami tingkah laku manusia berdasarkan perspektif partisipan tertentu secara langsung, (Carpenter \& Struebert, 1999). Fenomena yang diteliti adalah pengalaman keluarga menghadapi ketidakpatuhan klien skizofrenia menjalani regimen terapeutik: pengobatan. Partisipan penelitian adalah caregiver yang m-erupakan keluarga klien skizofrenia yang dirawat di ruang Srikandi RSMM Bogor. Partisipan penelitian diseleksi dengan teknik purposive sampling, berjumlah dua belas orang yang berasal dari sembilan keluarga klien.

Analisis data dilakukan dengan menggunakan teknik analisis Collaizi. Proses analisis data diawali dengan membaca berulang-ulang keseluruhan informasi yang tertuang dalam verbatim. Setelah itu menentukan pernyataan-pernyataan yang signifikan terkait dengan fenomena yang diteliti; menentukan kata kunci yang berasal dari pernyataan tersebut, dan mengategorikan kata-kata kunci yang memiliki arti yang relatif sama. Kemudian kategori yang sama dikelompokkan dalam satu sub-sub tema dan sub-sub tema yang sejenis dikelompokkan ke dalam sub tema yang lebih umum. Tema terbentuk dari pengelompokkan beberapa sub tema yang mengandung makna setara. Selanjutnya, peneliti merujuk kesesuaian tema yang terbentuk dengan tujuan khusus penelitian.

\section{Hasil}

Penelitian ini menghasilkan 10 tema yang berkaitan dengan pengalaman keluarga menghadapi ketidakpatuhan klien skizofrenia menjalani regimen terapeutik: pengobatan, yaitu; 1) persepsi partisipan tentang kepatuhan, 2) persepsi tentang ketidakpatuhan, 3) sumber dukungan keluarga, 4) bentuk dukungan keluarga terhadap klien, 5) beban keluarga sebagai caregiver, 6) koping positif keluarga, 7) koping negatif, 8) bentuk pelayanan yang diberikan perawat, 9) program peningkatan kepatuhan sebagai bentuk pelayanan yang diharapkan keluarga; dan 10) penerimaan tanggung jawab dan perubahan sikap sebagai makna merawat anggota keluarga yang tidak patuh terhadap pengobatan.

\section{Pembahasan}

Kepatuhan adalah tingkat perilaku klien (terhadap pengobatan, anjuran diet atau perubahan gaya hidup) terkait dengan saran dokter atau petugas kesehatan (Haynes, 1979, dalam Kyngas, 2000). Menurut Playle (1998), ketidakpatuhan minum obat pada klien gangguan jiwa merupakan suatu gejala penyakit, akibat ketidakmampuan berpikir logis dan bersikap patuh. Dalam kondisi ini tenaga kesehatan berhak memaksa pengobatan pada klien. Akan tetapi, dalam kondisi klien yang stabil (tidak mengalami gejala psikiatri), kepatuhan klien gangguan jiwa menjadi problematik, khususnya pada klien yang tidak menyadari dirinya sakit dan memerlukan obat profilaktif atau untuk mencegah kekambuhan pada klien.

Partisipan penelitian ini juga mengungkapkan persepsinya mengenai kepatuhan dan ketidakpatuhan. Gajski dan Karlovic (2008), membagi tingkat respon kepatuhan dalam suatu rentang, terdiri dari; 
kepatuhan sempurna, kepatuhan sebagian, kepatuhan sementara, meninggalkan pengobatan, dan kepatuhan yang berlebihan. Jika menggunakan kriteria ini maka kondisi klien penelitian termasuk kategori kepatuhan sebagian.

Kaplan dan Sadok (1997) menguraikan perilaku kepatuhan pada klien skizofrenia terdiri dari kepatuhan melakukan kontrol setelah perawatan, kepatuhan mengkonsumsi obat secara tepat, dan kepatuhan mengikuti anjuran tenaga kesehatan berupa perubahan pola hidup (contohnya cara mengatasi masalah) sesuai dengan psikoterapi yang diberikan. Hal ini disebabkan penelitian ini hanya meneliti faktor pengobatan, tidak meneliti kepatuhan terhadap saran yang diberikan pada sesi psikoterapi .

Perilaku ketidakpatuhan meliputi menghentikan minum obat, minum obat dengan dosis bukan seperti yang dianjurkan, minum obat tidak tepat waktu, dan penyalahgunaan obat (Husar, 1995). Sementara Kludge (2007) membagi perilaku ketidakpatuhan menjadi ketidakpatuhan yang disengaja dan ketidakpatuhan yang tidak disengaja. Pada penelitian ini, ketidakpatuhan yang disengaja terungkap berupa perilaku meningkatkan dan menurunkan dosis, serta menolak obat. Sementara ketidakpatuhan yang tidak disengaja berupa perilaku menunda waktu minum obat, sehingga akhirnya terlupa.

Fleischhacker, et al. (2003) mengungkapkan empat faktor penyebab yang mempengaruhi ketidakpatuhan klien skizofrenia, yaitu: faktor yang berhubungan dengan pengobatan, faktor yang berhubungan dengan klien, faktor yang berhubungan dengan lingkungan, dan faktor yang berhubungan dengan hubungan klien dan tenaga kesehatan. Hasil penelitian sesuai dengan pendapat Fleischhacker tersebut dengan diungkapkannya keempat faktor tersebut oleh keluarga sebagai faktor yang menyebabkan anggota keluarganya tidak patuh.

Penyebab tidak patuh dari aspek klien dan keluarga adalah rendahnya insight akan kondisi klien yang memerlukan obat dalam jangka waktu lama sebagai tindakan pencegahan kekambuhan. Efek samping, rasa obat, dan kompleksitas penggunaan obat merupakan penyebab ketidakpatuhan dari aspek obat. Adanya ungkapan yang bersifat menurunkan motivasi dan penjelasan yang kurang jelas adalah penyebab ketidakpatuhan dari aspek tenaga kesehatan.

Keluarga mendapat bantuan dari keluarga besar dan pihak non-keluarga dalam merawat klien di rumah. Hasil penelitian ini sesuai dengan hasil penelitian yang dilakukan oleh Seloilwe (2006) yang mengungkapkan adanya konsep collective and multiple caregiving, yaitu: keluarga tidak sendiri merawat klien gangguan jiwa dan keluarga juga harus merawat anggota keluarga yang lain. Dukungan keluarga merupakan salah satu sumber dukungan sosial yang mutlak dibutuhkan klien. Bart (1994) membagi dukungan keluarga menjadi empat bentuk dukungan, yaitu: dukungan instrumental, emosional, informasional, dan penilaian/ appraisal. Hasil dari penelitian ini menunjukkan bahwa seluruh bentuk dukungan tersebut telah diberikan oleh keluarga.

Garcia (2006) mengungkapkan bahwa dukungan instrumental merupakan prediktor kepatuhan klien saat di rumah. Dukungan instrumental yang diberikan meliputi seluruh aktivitas yang berorientasi pada tugas perawatan klien di rumah. Pada penelitian ini, dukungan instrumental dipenuhi keluarga dengan menyiapkan obat, melakukan pengawasan minum obat, mencari alternatif pemberian obat apabila klien tetap tidak mau minum obat, dan memenuhi kebutuhan finansial.

Dukungan emosional berupa ungkapan kasih sayang, empati, dan sikap menghargai sangat diperlukan klien skizofrenia. Pada penelitian ini, hanya satu partisipan yang memberikan dukungan emosional dalam bentuk ungkapan kasih sayang dengan memberikan semangat agar klien tetap mau minum obat. Menurut peneliti, dukungan ini sangat penting karena dengan kasih sayang yang diberikan keluarga terhadap klien, klien akan merasa dihargai dan dicintai. 
Kondisi ini memungkinkan klien kooperatif dan mau minum obat. Pendapat ini diperkuat oleh hasil penelitian Garcia (2006) yang mengungkapkan bahwa kehangatan dalam keluarga secara tidak langsung meningkatkan kepatuhan. Partisipan penelitian ini memberikan dukungan penilaian dengan memberikan umpan balik positif apabila klien menunjukkan perilaku patuh. Hal ini sesuai dengan konsep reward dan punishment yang menyatakan bahwa pemberian reward (salah satu bentuknya adalah pujian) digunakan untuk memperkuat perilaku positif, sehingga perilaku tersebut dapat dipertahankan.

Dukungan informasional dipenuhi partisipan dengan memberikan informasi pada anggota keluarga yang tidak mengerti tentang pengobatan klien gangguan jiwa. Merawat anggota keluarga yang tidak patuh, terutama jika klien mengalami kekambuhan dirasakan sebagai suatu beban keluarga (family burden). Family burden merupakan suatu istilah untuk mengidentifikasi berbagai permasalahan, kesulitan atau efek yang dialami keluarga sehubungan dengan adanya anggota keluarga yang mengalami gangguan jiwa yang berkepanjangan (Magliano, 2008).

Magliano membagi beban yang dirasakan keluarga menjadi 2 (dua) jenis beban, yaitu beban subjektif dan beban objektif. Beban subjektif adalah beban berupa perubahan emosional yang dialami caregiver berkaitan dengan tugas merawat penderita skizofrenia. Beban subjektif yang dialami partisipan berupa kecemasan, kesedihan, dan perubahan emosi. Beban objektif adalah berbagai beban dan hambatan yang dijumpai dalam kehidupan suatu keluarga yang berkaitan dengan perawatan penderita gangguan jiwa. Beban objektif yang dirasakan keluarga akibat ketidakpatuhan pada penelitian ini adalah gangguan hubungan dalam keluarga dan keterbatasan aktivitas.

Keluarga berupaya mengatasi beban yang dirasakan dalam merawat klien dengan mengembangkan strategi koping. Koping adalah upaya yang diarahkan pada penatalaksanaan stres termasuk upaya menyelesaikan masalah secara langsung dan mekanisme pertahanan yang digunakan untuk melindungi diri (Stuart, 2002). Partisipan penelitian ini menggunakan koping positif dan negatif.

Menurut Huang, et al. (2008), strategi koping positif adalah strategi koping yang berorientasi pada masalah, sementara strategi koping negatif adalah strategi koping yang berfokus pada emosi. Koping positif yang dilakukan keluarga adalah menghindari stressor, mencari dukungan keluarga, mencari pemecahan masalah, penilaian positif, menggunakan sistim sosial, mencari informasi, menggunakan fasilitas pelayanan kesehatan, dan melakukan aktivitas spiritual. Sementara, koping negatif yang dilakukan keluarga berupa tindakan pengabaian, seperti: tidak peduli terhadap kebutuhan klien dan membiarkan klien tidak patuh terhadap pengobatannya.

Asniar (2007) mengungkapkan sikap pengabaian atau neglect (melalaikan) merupakan kegagalan caregiver dalam memenuhi tanggung jawabnya untuk memberikan perawatan yang dibutuhkan. Penelantaran dapat terjadi dalam bentuk aktif (active neglect) dan pasif (passive neglect). Pengabaian aktif dilakukan keluarga akibat adanya konflik dalam keluarga. Pengabaian pasif dilakukan oleh partisipan akibat stres yang dirasakan dan kurangnya sumber daya (kemampuan mengatasi masalah ketidakpatuhan) keluarga. Menurut peneliti, selain faktor stres dan kurang sumber daya, pengabaian pasif terjadi akibat caregiver burn out yang dirasakan keluarga akibat kelelahan menghadapi ketidakpatuhan klien dan ketidakberhasilan keluarga membuat klien mau minum obat.

Hasil penelitian ini menunjukkan perawat memberikan beberapa bentuk pelayanan kepada klien maupun keluarga. Bentuk pelayanan yang diberikan kepada klien adalah pendidikan kesehatan dan pemantauan minum obat. Pelayanan yang diberikan pada keluarga berupa pendidikan kesehatan dan kegiatan self help group. Perawat menggunakan dirinya secara terapeutik (therapeutic use of self) dalam memberi pelayanan pada klien dan keluarga. 
Perkin (2002) mengidentifikasi bahwa beberapa strategi meningkatkan kepatuhan klien skizofrenia berdasarkan faktor yang menyebabkan ketidakpatuhan. Pada ketidakpatuhan yang bersumber dari faktor klien strategi yang dilakukan adalah pemberian terapi kognitif, pendidikan kesehatan tentang penyakit dan manfaat obat, memberikan memory aid (contohya bel tanda waktu minum obat).

Ketidakpatuhan yang berhubungan dengan faktor lingkungan sosial diatasi dengan memberikan pendidikan kesehatan dan dukungan untuk keluarga klien, meningkatkan akses ke pelayanan kesehatan jiwa yang ada seperti assertive case management dan melakukan kunjungan rumah, serta meningkatkan koordinasi antar pemberi pelayanan kesehatan. Ketidakpatuhan yang berhubungan dengan pengobatan diatasi dengan meminimalkan pemberian obat yang rumit, meminimalkan pengaruh efek samping obat terhadap kehidupan klien, memberi instruksi yang jelas tentang penggunaan obat, memberikan obat antipsikotik dengan efek ekstra piramidal yang minimal, meminimalkan efek terhadap peningkatan berat badan dan fungsi seksual.

Bentuk pelayanan yang diberikan oleh perawat pada klien dan keluarganya belum optimal jika dibandingkan dengan upaya strategi kepatuhan menurut Perkin (2000). Menurut peneliti, hal ini disebabkan karena belum adanya program khusus pencegahan kekambuhan yang dilaksanakan oleh ruangan Srikandi dan Rumah Sakit Marzoeki Mahdi. Selain itu pelayanan berbasis komunitas (Community Mental Health Nursing) di Indonesia baru dilaksanakan di daerah tertentu.

Partisipan juga mengungkapkan perawat sudah menggunakan dirinya secara terapeutik dalam menumbuhkan kepatuhan klien. Penggunaan diri perawat secara terapeutik terlihat dari adanya komunikasi yang efektif antara perawat dan klien, terbinanya hubungan saling percaya, dan adanya perhatian perawat yang dirasakan oleh klien dan keluarganya. Peneliti berpendapat therapeutic use of self harus dilakukan perawat dalam merawat klien dengan segala kondisi, termasuk kondisi klien yang tidak patuh terhadap pengobatan. Therapeutik use of self terlihat dari kemampuan perawat melakukan komunikasi yang jelas dan efektif, menghargai klien, dan mampu mengenali kelemahan dan kekuatan dirinya dalam rangka meningkatkan kesehatan klien. Dengan menggunakan diri sendiri secara terapeutik saat merawat klien, klien akan menjadi kooperatif dan akan menerima medikasi dengan tenang tanpa penolakan.

Kebutuhan akan pelayanan kesehatan mental yang diungkapkan oleh partisipan penelitian adalah pelayanan yang berkesinambungan, yaitu berupa follow up care. Secara spesifik keluarga mengharapkan adanya pemantauan kondisi klien di rumah melalui layanan telepon. Keluarga juga mengharapkan keberadaan perawat, terutama perawat yang merawat klien saat klien dirawat di rumah sakit pada saat keluarga melakukan follow up care. Kebutuhan terkait tindakan tenaga kesehatan yang diungkapkan partisipan adalah pendidikan kesehatan mengenai skizofrenia dan obat-obatannya. Pendidikan yang diberikan harus jelas dan diberikan sejak awal klien terdiagnosis skizofrenia.

Brewin (1992, dalam Agiananda, 2006) membagi kebutuhan keluarga akan perawatan kesehatan mental menjadi tiga, yaitu; kebutuhan akan perbaikan kesehatan, kebutuhan akan pelayanan kesehatan mental, dan kebutuhan akan tindakan dari tenaga kesehatan. Hasil penelitian ini menunjukkan keluarga membutuhkan pelayanan yang dapat membuat klien patuh terhadap pengobatan. Pelayanan yang diberikan harus dapat memenuhi harapan keluarga, sehingga meningkatkan kemandirian klien dalam minum obat, menumbuhkan kesadaran akan penyakit dan manfaat obat, serta kemampuan beradaptasi dengan efek samping.

Perilaku tidak patuh merupakan suatu stressor yang menetap bagi keluarga, seluruh partisipan mampu melihat hikmah atau makna positif dari keadaan tersebut. Partisipan mengatakan tetap menerima tanggung jawab (sebagai orang tua, istri, dan anak), untuk merawat anggota keluarganya dengan seluruh kondisi, termasuk kondisitidak patuh. 
Uraian tersebut menunjukkan sifat altruistik yang dimiliki partisipan dalam merawat anggota keluarga. Hal ini sesuai dengan penelitian yang dilakukan Rhoades dan McFarland (1999 dalam Asniar, 2007) mengungkapkan tiga makna yang dirasakan oleh keluarga yang merawat anggota keluarga dengan gangguan jiwa yaitu altruistik yang ditujukan pada orang lain, aktualisasi diri yang ditujukan pada diri sendiri dan tujuan eksistensial dalam hidup.

\section{Kesimpulan}

Hasil penelitian menggambarkan fenomena ketidakpatuhan merupakan cerminan terputusnya continuity of care akibat ketidakmampuan klien dan keluarga mempertahankan kepatuhan terhadap pengobatan. Klien dan keluarga kurang memahami bahwa minum obat dalam jangka waktu panjang adalah penting dan dibutuhkan klien untuk mencegah kekambuhan. Rendahnya kesadaran klien dan keluarga merupakan salah satu penyebab penghambat kepatuhan. Kondisi ini seyogyanya menimbulkan perasaan empati perawat untuk mengatasi masalah ketidakpatuhan. Salah satu tindakan yang dapat dilakukan perawat adalah menumbuhkan dan meningkatkan kesadaran tersebut.

Keluarga sebagai caregiver klien dirumah menghadapi berbagai hambatan dan menanggung beban dalam merawat klien yang tidak patuh. Kondisi ini mengingatkan perawat bahwa target layanan keperawatan jiwa bukan hanya klien. Namun, keluarga juga sebagai kelompok rentan stres sebagai konsekuensi merawat klien gangguan jiwa di rumah. Apabila keluarga dapat melasanakan peran perawatan klien di rumah tanpa tekanan/stres maka keluarga akan optimal menjalankan fungsi perawatan kesehatan anggota keluarganya (DN, BK, KN).

\section{Referensi}

Asniar. (2007). Study fenomenologi terhadap pengalaman keluarga merawat anggota keluarga pasca stroke di rumah (Tesis master, tidak dipublikasikan). FIK UI, Jakarta.

Agiananda, F. (2006). Pengkajian, beban, kebutuh an dan sumber daya keluarga dalam merawat penderita skizofrenia: Sebuah studi kasus (Tesis master, tidak dipublikasikan). FK UI, Jakarta.

Bart, S. (1994). Psikologi kesehatan. Jakarta: Grasindo

Fleischhacker, W., Oehl, M.A., \& Hummer, M. (2003). Factors influencing compliance in schizophrenia patients. J Clin Psychiatry, 64 (suppl 16), 10-13.

Gajski, A. \& Karlovic. (2008). Assesment of nurse attitudes on psychiatric patient compliance with pharmacotherapy. Acta Clin Croat, 47, 149-153.

Garcia, R. (2006). Family support predict psychiatric medication usage among Mexican American individuals with schizophrenia. Diperoleh dari http://web.ebscohost.com.

Husar, D. (1995). Helping your patient follow his drug regimen. Nursing, 25 (10), 62.

Kaplan, H.I., Sadock, B.J., \& Grebb, J.A. (1997). Sinopsis Psikiatri (7th Ed.). Jakarta: Aksara.

Kluge, C., Schuster, T., et al. (2007). Partial compliance with antipsychotic edication is common in patients with schizoprenia. Australian and New Zealand Journal of Psychiatry, 2008 (42), 382-388.

Kyngas, H., Duffy, M.E., et al. (2000). Conceptual analysis of compliance. $J C N, 9,5-12$.

Magliano, L. (2008). Families of People with severe mental disorders: Difficulties and resources. Diperoleh dari http//www.euro.who.int/document/ $\mathrm{MNH} /$ family-burden.

Perkin, D.O.(2002). Predictors of noncompliance in patients with Schizoprenia. Journal of Clinical Psychiatry, 63 (12), 1121-1128.

Playle, J.F., \& Keelay, P. (1998). Non-compliance and professional power. $J A N, 27$ (2), 304-311.

Seloilwe, E.S. (2006). Experiences and demands of families with mentally ill people at home in Botswana. Journal of Nursing Scholarship, 38 (3), 262-268.

Streubert, \& Carpenter. (1999). Qualitative research in nursing advancing the humanistic imperative. Philadelphia: Lipincott.

Stuart, G.W. (2002) Pocket guide To psychiatric nursing (5th Ed.). St. Louis: Mosby, Inc.

Stuart, G.W., \& Laraia, M.T. (2005). Principles and practice of psychiatric nursing ( 7 th Ed.). St Louis: Mosby, Inc. 